This paper was first published in Hispania 89.2 (2006): 366-368. The author wishes

to acknowledge with thanks the permission from AATSP to provide this copy to the

Institutional Repository of CSU Channel Islands.

\title{
To Speak or Not to Speak?: Drama Techniques, Narration and Other Real-Life Activities
}

\author{
Terry L. Ballman \\ California State University Channel Islands
}

\begin{abstract}
Although students report that they are interested in learning to speak Spanish, they often seem reticent to do so. The conference presentation summarized below was a three-hour workshop in which a brief overview was provided on the importance of communicative classroom interaction practices and the Standards for Foreign Language Learning. The bulk of the session was dedicated to illustrating numerous dramatic, narrative, and real-life activities to promote student oral proficiency.
\end{abstract}

Key Words: classroom interaction, drama techniques, narration, oral proficiency, real-life activities

$\mathrm{M}$ ost second/foreign language teachers are familiar with communicative language teaching practices as well as the Standards for Foreign Language Learning in the $21^{\text {s' }}$ Century (1996), and express a commitment to practices that reflect the exchange of meaning over the practice of form. Research on classroom interaction suggests, however, that there are practices common to many language classrooms which may undermine these stated pedagogical goals. Several practices that may discourage students from speaking include: asking more display [when answers are obvious] than referential questions, for example, iDe que color es tu camisa? vs. iCudl es tu color favor ito?; insisting that students answer in complete sentences, when in natural speech only a sentence fragment would be used; and correcting students in the middle of a communicative exchange. (For a brief review of the literature and numerous examples, see Ballman, Liskin-Gasparro and Mandell, 134-67.)

Our classrooms should provide students with the best opportunities to develop their oral language skills, which include using appropriate vocabulary and grammar; developing discourse; and showing an awareness of audience by using appropriate tone and register. Drama techniques allow students to take on another persona and character, and in so doing be less selfconscious. Narrative activities evoke the power of story-telling. And real-life activities remind our students about why we use language.

A brief description of several of the activities presented in the session is given below. The categories are: Drama Techniques, Narration, and Real-Life Activities.

\section{Drama Techniques:}

1. The hand-shake. Participants were asked to greet, without speaking, the following people: their son's new girlfriend, the Queen of England, their best friend, the president of Mexico. This activity illustrates that a great deal of information can be conveyed non-verbally. Participants were then asked to do this again, now using speech. Here the issues of formal and informal. registers were discussed.

2. Mimicry. Participants were asked to act out a prompt given them, with the group identifying who the person is and what he or she is doing. Example: You're the Mona Lisa, posing for your portrait; You're a traffic cop, directing traffic; You're a parachutist, getting ready to jump (see Maley and Duff, for more suggestions.)

3. Role-plays. First, guidelines for creating role-plays were discussed. Whereas novice speakers need to be provided a great deal of structure (e.g., Your older brother is away from home for the first time. Greet him, ask him about his roommate, and find out if he likes his classes), 
advanced speakers can be provided much more latitude (e.g., You have witnessed an accident, and you need to explain to the police officer exactly what happened.) A scenario that can be adjusted to appropriate language level is:

Customer: You bought an expensive dress on sale. The first night you wear it, a button falls off. You try to return it. Sales clerk: The customer cannot return a sales item.

4. Making a video. Students work individually or with partners to produce a short video. The script must tell a story and have a beginning, middle and end. Once the script is approved by the instructor, students begin filming. The higher the level, the longer the video must be. Students are evaluated on: meeting deadlines for script correction and filming, video length, exclusive use of Spanish, correctness and use of Spanish, plot structure and cultural elements, props and costumes. (For a description of this and numerous other activities, with accompanying scoring rubrics, see Petersen.)

\section{Narration}

1. Using visual prompts. Students are asked to describe orally a picture. They are asked to speak for as long as they can, without repeating information. This activity can be repeated with a series of pictures or drawings that tell a story, with or without a conclusion provided. It was suggested that instructors time students at the beginning and ending points of an instructional term. Students feel empowered when they see improvement in their speech; for example, being able to speak for only 30 seconds at the beginning of the term as compared to being able to speak for three minutes by the end of the term.

2. Truths and Lies. To model the activity, the instructor tells three stories about his or her life, with two being true and one being false. The class tries to identify which story is false, and may ask clarification questions. Students are then asked to carry out this activity, first in small groups, and then before the class. (For more information about this and other narrative activities, see Wajnryb.)

3. Anecdotes. From a list, students are divided into groups, and group members share anecdotes. Later, a representative from each group shares his or her anecdote with the class (e.g., el dia mas importante de mi vida, un evento que me causo mucho sustg, un evento muy vergonzoso, la ultima vez que me rei a carcajadas). Students are asked to be as descriptive as possible. The class later votes on: the best anecdote, the funniest, the saddest, the most descriptive.

4. Rewriting lyrics. Students work in small groups and each group is given lyrics of a song that tells a story, e.g., "Un ramito de violetas" and "Hijo de la luna." Students are asked to write lyrics to tell an original story, and the new lyrics should fit with the song's melody. Each group is asked to sing its lyrics to the class.

\section{Real-life activities}

1. Leave your teacher a message. Students are asked to call their instructor (during off hours) and leave a message on his or her answering machine. The message must be spontaneous, and contain four bits of information: their name, the date, the time called, and a message. (See Ballman, etal, 115-16).

2. Giving advice. Students, working in pairs or small groups, are asked to give advice to incoming freshmen on how to succeed in high school, or how to succeed in college. As each pair or group presents, the class takes on the role of the freshmen, asking appropriate follow-up questions. The class may later vote on the best all-around advice and/or the funniest advice.

3. Dubbing a movie. Students working in groups of three or four are asked to choose a Spanish-language movie, and to identify 6-8 minutes of footage. They are asked to write an original script, and to act out the pertinent scenes and record them. Students are evaluated by their peers and by their instructor on originality, dramatization, grammaticality and special effects.

Language teachers must make sure that they use classroom practices that encourage students to become successful speakers of the target language. When learners use Spanish (or Portuguese) to carry out a particular task, particularly if the task involves drama, story-telling or 
authentic, real-life activities, students may be much more willing to participate, be engaged, and take risks as they develop their oral proficiency.

\section{WORKS CITED}

Ballman, Terry L., Judith E. Liskin-Gasparro and Paul B. Mandell. The Communicative Classroom. Boston, MA: Heinle and Heinle, 2001.

Maley, Alan and Alan Duff. Drama Techniques in Language Learning. Cambridge, UK: Cambridge UP, 1983.

National Standards in Foreign Language Education Project. Standards for Foreign Language Learning: Preparing for the Twentieth-First Century. Lawrence, KS: Allen Press, 1996.

Petersen, Wade. 50 Spanish Oral Communication Activities with Mini-Rubrics. Auburn Hills, MI: Teacher's Discovery, 1999.

Wajnryb, Ruth. Stories: Narrative Activities in the Language Classroom. Cambridge, UK: Cambridge UP, 2003. 